\title{
Effects of Saffron Corm and Leaf Extracts on Early Growth of Some Plants to Investigate the Possibility of Using Them as Associated Crop
}

\author{
Hamid-Reza FALLAHI ${ }^{1 *}$, Arezoo PARAVAR ${ }^{2}$, Mohammad-Ali BEHDANI ${ }^{1}$, \\ Mahsa AGHHAVANI-SHAJARI ${ }^{3}$, Mohammad-Javad FALLAHI ${ }^{4}$ \\ ${ }^{1}$ Birjand University, Saffron Research Group, Birjand, Iran; Hamidreza.fallahi@birjand.ac.ir (*correspondingauthor), Mabehdeni@yahoo.com \\ ${ }^{2}$ Shahed University, Faculty of Agriculture, Tehran, Iran; Paravararezoo@yahoo.com \\ ${ }^{3}$ Ferdowsi University of Mashhad, Faculty of Agriculture, Mashhad, Iran; Mahsashajari@yahoo.com \\ ${ }^{4}$ South Khorasan Province governorship, Birjand, Iran; Mohamadjavadfallabi@yahoo.com
}

\begin{abstract}
Saffron intercropping with other plants needs to preliminary investigations about the possible negative interactions between saffron and associated crop. In this study, allelopathic effects of saffron leaf and corm extracts on germination and seedling growth indices of alfalfa (Medicago sativa), arugula (Eruca sativa) and rapeseed (Brassica napus) was investigated in six separate experiments based on completely randomized design. Experimental treatments were consisted of different levels of saffron leaf and corm extracts including $0,0.75,1.5,3$ and $6 \%$. The maximum germination percentage of all selected crops was obtained at control treatment (on average $92 \%$ ) and then decreased with increasing extracts concentration. So that, the germination percentage of arugula, canola and alfalfa in highest concentration of extracts were 18,10 and $8 \%$ for leaf extract and 72, 68 and $93 \%$ for corm extract, respectively. The relatively similar trend was observed about germination rate, root and plumule lengths and dry weights. Therefore, the inhibitory effect of saffron leaf extract was more than corm extract on initial growth indices of studied plants. The lowest inhibitory effect of saffron leaf extract and even relatively high stimulatory effect of corm extract were obtained on alfalfa initial growth criteria. Considering the differences in allelochemicals mode of action and concentrations in laboratory bioassays with natural condition, it is necessary to investigate the effects of saffron residues on growth of selected associated crops in greenhouse and field scales for the final decision.
\end{abstract}

Keywords: alfalfa, allelopathy, arugula, canola, germination rate

\section{Introduction}

Saffron (Crocus sativus L.) as the most expensive agricultural and pharmaceutical product of the world has a specific place in export products of Iran (Akbarpour et al., 2013). This spicy and medicinal plant has about 62000 ha area under cultivation with about 210 tons annual production in Iran, which includes about $90 \%$ of its world production (Mohammad-Abadi et al., 2011; RezvaniMoghaddam et al., 2011,2013).

Saffron as a summer dormant and winter active plant is one of the most efficient plants in terms of water consumption (Kumar et al., 2009; Khazaei et al., 2013). This slow-growing plant has acerate narrow leaves and no aerial stem hence; weeds can be overcome it (Shabahang $e t$ al., 2013). Moreover, because of its root and canopy structure an important part of different resources is not used by this low input crop (Khosray, 2005; Koocheki et al., 2013; Shabahang et al., 2013). Therefore, the use of associated crops could be an effective way for increasing resources use efficiencies such as radiation, water and nutrient (Koocheki et al., 2013). In addition, irrigation during dormant period of saffron growth (summer) is negative for its growth and yield (Khazaei et al., 2013). Hence, it is necessary that selected associated crop be a winter, low input (water and nutrient) crop and its growth period be in maximum coincidence with saffron growth (Koocheki et al., 2013). So far, results of some studies have shown that saffron intercropping with suitable crops such as caraway (Bonium persicum L.), persian clover (Trifolium resopinatum), pea vine (Lathyrus annus), chamomile species (Matricaria chamomilla, Tanacetum parthenium and Anthemis nobilis), vetch (Vicia sativa) and arugula (Eruca sativa) has an important role in weed control, saffron yield increase and improving land equivalent ratio due to improvement in soil characteristics and enhancement in nutrient and nitrogen availability especially through nitrogen fixation (Khosravi, 2005; Naderi-Darbaghshahi et al., 2012; Koocheki et al., 2013; Shabahang et al., 2013).

In addition to mentioned properties for selected associated crop, there should be no mutual negative allelopathic effects between saffron and associated plant. It has been reported that saffron has negative or positive allelopathic effects on some plants (Eghbali et al., 2007; 
Rashed-Mohassel et al., 2008; Abbassi and Jahani, 2008; Soufizadeh et al., 2008; Khazaei et al., 2013). Therefore, the aim of this study was to investigate the possible allelopathic effects of saffron corm and leaf extracts on germination and initial seedling growth of alfalfa, arugula and rapeseed as selected associated crops.

\section{Material and methods}

Allelopathic effects of saffron leaf and corm extracts on germination and initial seedling growth indices of alfalfa, arugula and rapeseed were investigated in six separate experiments. These experiments were performed based on Completely Randomized Design, with three replicates of 20 seeds at crop physiology laboratory of Agriculture Faculty of Sarayan, Birjand University in 2013. The experimental treatments were consisted of different concentrations of saffron leaf and corm extracts including $0,0.75,1.5,3$ and 6 $\%$. The leaves and corms of saffron were dried separately in $75{ }^{\circ} \mathrm{C}$ for 72 hours and then were grounded. After that, appropriate values of milled leaf and corm residue (including $0.0 .75,1.5,3$ and 6 gr of each powder) were separately dissolved in $100 \mathrm{ml}$ of distillated water and then samples were extracted after 24 hours.

Before running the experiment, seeds were disinfected using hypochlorite sodium (7\%) for seven minutes. After that, seeds were germinated in sterilized petri-dishes $(9 \mathrm{~cm}$ diameter) with one filter papers moistened by adding $6 \mathrm{ml}$ of appropriate extracts. The trays containing petri-dishes were supplied with ample water and were put into sealed plastic bags to prevent evaporation and therefore maintain approximately $100 \%$ relative humidity within each tray throughout the germination test (Fallahi et al., 2013). Germinated seeds were counted two times per day (in the morning and the evening) for seven days. On the final day germination percentage and root and plumule lengths were determined and then these seedling organs were isolated separately and then were dried in oven at $72^{\circ} \mathrm{C}$ for 48 hours for determining root and plumule dry weights. Moreover, germination rate was calculated using the Maguire formula (Fallahi et al., 2013).

Data analysis was done using SAS 9.1 and treatment means were compared using Duncan's multiple range test at $5 \%$ level of probability.

\section{Results and Discussion}

\section{Effects of saffron leaf and corm extract on seedling growth incices of arugula}

Saffron leaf and corm extracts affected significantly almost all germination and early seedling growth indices of arugula (Tab. 1). Germination percentage and rate decreased with slow non-significant trend up to $3 \%$ concentration of leaf extract and then reduced considerably. These indices in response to increase in corm extract concentrations showed reduction, but with slower trend (Tab. 2). Morovere, saffron leaf and corm extracts reduced root and plumule lengths and weights of arugula, but negative effect of leaf extract was some more, especially at highest extract concentration (Tab. 2).

Allelopathy referred to both direct or indirect and either beneficial or deleterious effects of a plant (including microorganisms) on another plant through the release of allelochemicals in the environment ( $\mathrm{Li}$ et al., 2010). Although, this effect may result in positive outcomes, but generally it is considered to have negative effects on the other plant (Han et al., 2013). Allelochemicals may affect the plant growth by altering the physiological processes such as photosynthesis, respiration, cellular expansion, cell wall construction, pigment synthesis, protein synthesis, phytohormonal balance, mineral uptake, stomatal movement, nitrogen fixation and plant water relations (Nasr Isfahan and Shariati, 2007). According to current preliminary results, saffron corm and leaf extracts had no considerable negative effects on initial growth of arugula up to middle concentrations of extracts. Moreover, current results obtained in petri-dish condition that is very different from natural condition, especially in terms of allelochemical concentration; because these compounds taking different pathways in the soil environment including plant uptake, leaching, incorporating into organic matter, adsorbing by inorganic soil constituents, microbial breakdown and physical and chemical degradation (De-Albuquerque et al., 2011). So that, in a greenhouse study it has been reported that the effects of saffron corm and leaf residue not only were not inhibiting on early growth of arugula but also improved some of its growth traits (Fallahi and Davarzani, 2013).

Tab. 1. Analysis of variance (sum of square) for the effects of different levels of saffron corm and leaf extract on germination and seedling growth criteria of arugula

\begin{tabular}{|c|c|c|c|c|c|c|c|}
\hline $\begin{array}{c}\text { Mean dry } \\
\text { plumule weight }\end{array}$ & $\begin{array}{l}\text { Mean dry } \\
\text { root weight }\end{array}$ & $\begin{array}{c}\text { Mean plumule } \\
\text { length }\end{array}$ & $\begin{array}{l}\text { Mean root } \\
\text { length }\end{array}$ & $\begin{array}{l}\text { Germination } \\
\text { rate }\end{array}$ & $\begin{array}{l}\text { Germination } \\
\text { percentage }\end{array}$ & $\mathrm{df}$ & $\begin{array}{c}\text { Sources of } \\
\text { variation }\end{array}$ \\
\hline \multicolumn{8}{|c|}{ Leaf extract } \\
\hline $0.00086^{* *}$ & $0.0006^{* *}$ & $19.96^{* *}$ & $52.11^{* *}$ & $131.5^{* *}$ & $11423.3^{* *}$ & 4 & Treatment \\
\hline 0.00006 & 0.0000 & 5.54 & 9.76 & 4.4 & 916.6 & 10 & Error \\
\hline 0.00093 & 0.0006 & 25.5 & 61.88 & 135.9 & 12340 & 14 & Total \\
\hline \multicolumn{8}{|c|}{ Corm extract } \\
\hline $0.0002^{* *}$ & $0.0002^{* *}$ & $9.28^{* *}$ & $48.37^{* *}$ & $35.0^{* *}$ & $1076.6^{* *}$ & 4 & Treatment \\
\hline 0.0002 & 0.0001 & 6.34 & 5.27 & 1.4 & 216.6 & 10 & Error \\
\hline 0.0004 & 0.0003 & 15.63 & 54.01 & 36.5 & 1293.3 & 14 & Total \\
\hline
\end{tabular}


Saffron is a short-statured crop and grows very slowly especially in the first years of its growth; therefore, the use of associated crops such as arugula has proper performance on weed control and saffron yield (Zare-Hossiney 2011). Saffron mainly uses from winter irrigation and precipitation and is grown in arid and semi-arid parts of Iran that are faced with water poverty, thus it is better that the selected associated crop be a winter, drought resistant crop (ZareHossiney, 2011; Koocheki et al., 2013). Arugula is a fast growing, cool season crop with short production cycle and drought tolerant capacity that is grown on marginal lands with poor fertility (Jakhar et al., 2010; Jakse et al., 2013). Therefore, it seems that this plant could be considered as a good choice for intercropping with saffron.

Tab. 2. Mean comparisons of the effects of different levels of saffron corm and leaf extracts on germination and seedling growth criteria of arugula

\begin{tabular}{|c|c|c|c|c|c|c|}
\hline $\begin{array}{l}\text { Mean dry plumule } \\
\text { weight (gr) }\end{array}$ & $\begin{array}{c}\text { Mean dry root } \\
\text { weight (gr) }\end{array}$ & $\begin{array}{l}\text { Mean plumule } \\
\text { length }(\mathrm{cm})\end{array}$ & $\begin{array}{l}\text { Mean root } \\
\text { length }(\mathrm{cm})\end{array}$ & $\begin{array}{c}\text { Germination } \\
\text { rate (seed per } 12 \\
\text { hours) }\end{array}$ & $\begin{array}{l}\text { Germination } \\
\text { percentage }\end{array}$ & $\begin{array}{l}\text { Treatment (extract } \\
\text { concentration) }\end{array}$ \\
\hline \multicolumn{7}{|c|}{ Leaf extract } \\
\hline $0.02 \mathrm{a}$ & $0.02 \mathrm{a}$ & $3.2 \mathrm{a}$ & $4.9 \mathrm{a}$ & $10.3 \mathrm{a}$ & $91.6 \mathrm{a}$ & $0.0 \%$ \\
\hline $0.01 \mathrm{a}$ & $0.01 \mathrm{a}$ & $2.3 \mathrm{ab}$ & $3.7 \mathrm{ab}$ & $6.8 \mathrm{~b}$ & $88.3 \mathrm{a}$ & $0.75 \%$ \\
\hline $0.02 \mathrm{a}$ & $0.01 \mathrm{~b}$ & $2.8 \mathrm{a}$ & $2.8 \mathrm{~b}$ & $6.9 \mathrm{~b}$ & $86.6 a$ & $1.5 \%$ \\
\hline $0.01 \mathrm{~b}$ & $0.01 \mathrm{~b}$ & $1.3 \mathrm{bc}$ & $0.7 \mathrm{c}$ & $6.0 \mathrm{~b}$ & $80.0 \mathrm{a}$ & $3.0 \%$ \\
\hline $0.00 c$ & $0.00 c$ & $0.0 \mathrm{c}$ & $0.0 \mathrm{c}$ & $1.1 \mathrm{c}$ & $18.3 b$ & $6.0 \%$ \\
\hline \multicolumn{7}{|c|}{ Corm extract } \\
\hline $0.02 \mathrm{a}$ & $0.02 \mathrm{a}$ & $3.2 \mathrm{ab}$ & $4.9 \mathrm{a}$ & $10.3 \mathrm{a}$ & $91.6 \mathrm{a}$ & $0.0 \%$ \\
\hline $0.02 \mathrm{a}$ & $0.01 \mathrm{ab}$ & $3.9 a$ & $5.1 \mathrm{a}$ & $7.6 \mathrm{~b}$ & $90.0 \mathrm{a}$ & $0.75 \%$ \\
\hline $0.01 \mathrm{ab}$ & $0.01 \mathrm{ab}$ & $2.8 \mathrm{ab}$ & $2.0 \mathrm{~b}$ & $7.04 \mathrm{cb}$ & $91.6 \mathrm{a}$ & $1.5 \%$ \\
\hline $0.01 \mathrm{ab}$ & $0.01 \mathrm{~b}$ & $1.8 \mathrm{~b}$ & $1.9 \mathrm{~b}$ & $6.5 c$ & $76.6 b$ & $3.0 \%$ \\
\hline $0.01 \mathrm{~b}$ & $0.01 b$ & $1.9 \mathrm{~b}$ & $0.6 \mathrm{c}$ & $5.8 \mathrm{~d}$ & $71.6 \mathrm{~b}$ & $6.0 \%$ \\
\hline
\end{tabular}

Means with the same letters in each column are not significantly different at the 0.05 level of probability.

\section{Effects of saffron leaf and corm extract on seedling growth incices of canola}

Effects of saffron leaf and corm extracts were significant on almost all germination and primary seedling growth criteria of rapeseed (Tab. 3). Germination percentage didn't reduce significantly up to $3 \%$ concentration of leaf extract, but it decreased about $89 \%$ in $6 \%$ concentration compare to control treatment. The negative effect of corm extracts on germination percentage wasn't considerable in comparison with leaf extracts, so that the amount of this index decreased about $25 \%$ in $6 \%$ concentration compared to control treatment (Tab. 4). Germination rate and root and plumule lengths decreased with increasing in leaf and corm extract concentrations but the negative effect of leaf extract was more, especially at highest extract concentration (Tab. 4). Root and plumule weights of rapeseed seedlings showed no reduction up to $1.5 \%$ concentration of leaf extract and then decreased until reached to zero in highest extract concentration, while the amounts of mentioned indices showed no significant difference in various levels of corm extract (Tab. 4).

Allelopathic compounds that are released into the environment through root exudation, leaching, volatilization and decomposition, often inhibit the germination or growth of neighboring plants, although sometimes they may exert a stimulating effect (Pirzad et al., 2010; Moosavi et al., 2011). Allelopathy has an important role in ecosystems mainly by affecting germination and seedling growth through negative or positive altering of physiological functions like respiration, photosynthesis and ion uptake (Chon and Nelson, 2010). Moreover, it has been reported that allelochemicals probably affect inducible hormones of germination such as gibberellin or activity of some enzymes like amylases and proteinases, which are necessary for seed germination (Nasr Isfahan and Shariati, 2007). Current bioassay results showed that there was no considerable inhibitory effect on rapeseed initial growth up to middle levels of saffron leaf and especially corm extract (Tab. 4). Moreover, the effect of allelochemicals in bioassay using petri-dishes could be different from their action in soil environment, because allelochemicals in soil enter to a complex plant-soil system in which different factors such as binding to organic matter and clays, leaching and physiochemical and microbial processes, affect their availability and concentration and consequently their effective influence on target plants. Moreover, microbiological transformations can either detoxify the soil of these compounds or produce other allelochemicals with more phytotoxicy (De-Albuquerque et al., 2011). Therefore, it seems that more studies is need in soil environment for final decision about intercropping of rapeseed with saffron.

Saffron is a slow growing and narrow leaf plant without aerial stem which makes weeds overcome on it and absorb water, nutrients and radiation (Zare-Hossiney 2011). Therefore, the use of associated crops for replacing weeds with manageable cover crops is a suitable way for weeds control and maximizing the use of resources (Koocheki $e t$ al., 2013). It seems that accurate selection of associated crops could led to low inhibitory interaction between saffron and associated crop or even weed suppression by inhibitory allelopathic effects of associated crop (Koocheki et al., 2013). Rapeseed as a winter crop by appropriate growth coincidence with saffron growth period could be a good option for intercropping with this plant. 
Tab. 3. Analysis of variance (sum of square) for the effects of different levels of saffron corm and leaf extracts on germination and seedling growth indices of rapeseed

\begin{tabular}{cccccccc}
\hline $\begin{array}{c}\text { Mean dry } \\
\text { plumule weight }\end{array}$ & $\begin{array}{c}\text { Mean dry root } \\
\text { weight }\end{array}$ & $\begin{array}{c}\text { Mean plumule } \\
\text { length }\end{array}$ & $\begin{array}{c}\text { Mean root } \\
\text { length }\end{array}$ & $\begin{array}{c}\text { Germination } \\
\text { rate }\end{array}$ & $\begin{array}{c}\text { Germination } \\
\text { percentage }\end{array}$ & $\begin{array}{c}\text { Sources of } \\
\text { variation }\end{array}$ \\
\hline $0.00086^{* *}$ & $0.0009^{* *}$ & $28.1^{* *}$ & $127.6^{* *}$ & 175.5 & 14383.3 & 4 & Treatment \\
0.00006 & 0.0000 & 8.1 & 10.8 & 10.5 & 900.0 & 10 & Error \\
0.00093 & 0.0009 & 36.2 & 138.5 & 186.0 & 15283.3 & 14 & Total \\
0 & & Corm extract & & \\
$0.0001 \mathrm{~ns}$ & $0.00022^{* *}$ & $5.3^{* *}$ & $70.6^{* *}$ & $78.1^{* *}$ & $1293.3^{* *}$ & 4 & Treatment \\
0.0002 & 0.00006 & 2.7 & 8.1 & 10.7 & 816.6 & 10 & Error \\
0.0003 & 0.00029 & 8.0 & 78.8 & 88.8 & 2110 & 14 & Total \\
\hline ns, not significant. ${ }^{*}$ significant in 5\% levels. and ${ }^{* *}$ significant in 1\% level of probability. & & &
\end{tabular}

Tab. 4. Mean comparisons of the effects of different levels of saffron corm and leaf extracts on germination and seedling growth criteria of rapeseed

\begin{tabular}{|c|c|c|c|c|c|c|}
\hline $\begin{array}{c}\text { Mean dry } \\
\text { plumule weight } \\
\text { (gr) }\end{array}$ & $\begin{array}{c}\text { Mean dry root } \\
\text { weight (gr) }\end{array}$ & $\begin{array}{l}\text { Mean plumule } \\
\text { length }(\mathrm{cm})\end{array}$ & $\begin{array}{l}\text { Mean root } \\
\text { length }(\mathrm{cm})\end{array}$ & $\begin{array}{l}\text { Germination } \\
\text { rate (seed per } 12 \\
\text { hours) }\end{array}$ & $\begin{array}{l}\text { Germination } \\
\text { percentage }\end{array}$ & $\begin{array}{c}\text { Treatment } \\
\text { (extract } \\
\text { concentration) }\end{array}$ \\
\hline \multicolumn{7}{|c|}{ Leaf extract } \\
\hline $0.02 \mathrm{a}$ & $0.02 \mathrm{a}$ & $3.3 \mathrm{ab}$ & $8.0 \mathrm{a}$ & $10.9 \mathrm{a}$ & $91.6 \mathrm{a}$ & $0.0 \%$ \\
\hline $0.01 \mathrm{a}$ & $0.02 a$ & $4.2 \mathrm{a}$ & $4.0 \mathrm{c}$ & $7.3 \mathrm{~b}$ & $83.3 \mathrm{a}$ & $0.75 \%$ \\
\hline $0.02 \mathrm{a}$ & $0.02 \mathrm{a}$ & $4.3 \mathrm{a}$ & $6.1 \mathrm{~b}$ & $6.7 \mathrm{~b}$ & $85.0 \mathrm{a}$ & $1.5 \%$ \\
\hline $0.01 \mathrm{~b}$ & $0.01 \mathrm{~b}$ & $2.4 \mathrm{~b}$ & $1.1 \mathrm{~d}$ & $3.4 \mathrm{c}$ & $46.6 b$ & $3.0 \%$ \\
\hline $0.0 \mathrm{c}$ & $0.0 \mathrm{c}$ & $0.6 \mathrm{c}$ & $0.4 \mathrm{~d}$ & $0.9 \mathrm{~d}$ & $10.0 \mathrm{c}$ & $6.0 \%$ \\
\hline \multicolumn{7}{|c|}{ Corm extract } \\
\hline $0.020 \mathrm{a}$ & $0.020 \mathrm{a}$ & $3.33 \mathrm{ab}$ & $8.07 \mathrm{a}$ & $10.9 a$ & $91.6 \mathrm{a}$ & $0.0 \%$ \\
\hline $0.013 \mathrm{a}$ & $0.013 b$ & $2.53 \mathrm{cb}$ & $4.08 \mathrm{~b}$ & $7.3 \mathrm{~b}$ & $95.0 \mathrm{a}$ & $0.75 \%$ \\
\hline $0.013 \mathrm{a}$ & $0.010 \mathrm{~b}$ & $2.46 \mathrm{cb}$ & $3.0 \mathrm{bc}$ & $5.5 \mathrm{bc}$ & $83.3 \mathrm{ab}$ & $1.5 \%$ \\
\hline $0.013 \mathrm{a}$ & $0.010 \mathrm{~b}$ & $3.68 \mathrm{a}$ & $3.4 \mathrm{~b}$ & $5.7 b c$ & $81.6 \mathrm{ab}$ & $3.0 \%$ \\
\hline $0.020 \mathrm{a}$ & $0.010 \mathrm{~b}$ & $2.06 \mathrm{c}$ & $1.5 \mathrm{c}$ & $4.3 \mathrm{c}$ & $68.3 \mathrm{~b}$ & $6.0 \%$ \\
\hline
\end{tabular}

\section{Effects of saffron leaf and corm extracts on seedling growth indices of alfalfa}

Effects of saffron leaf extract was significant on all germination and early seedling growth indices of alfalfa, while only germination rate and mean root length criteria were affected significantly by corm extract (Tab. 5). Germination percentage didn't considerably affect up to $3 \%$ concentration of leaf extract and after that decreased strongly (Tab. 6). Amount of germination rate was lower than control treatment in all leaf extract concentrations, especially at highest level of extract. Mean root and plumule lengths increased up to $0.75 \%$ treatment and then decreased until reached to zero in highest concentration of leaf extract. The values of mean dry weights of root and plumule showed no decrease up to $3 \%$ concentration of leaf extract and after that reduced significantly (Tab. 6). The effects of saffron corm extract on germination and early seedling growth indices of alfalfa wasn't inhibiting or even sometimes was stimulatory. Amount of germination percentage didn't show significant difference between treatments while, amount of germination rate was more in control treatment, without significant difference between other treatments (Tab. 6). Amounts of mean root and plumule lengths were higher in all levels of corm extract compared to control treatment. Moreover, root and plumule mean weights didn't show any significant difference between various levels of saffron corm extract (Tab. 6).
Saffron couldn't use properly from environmental factors such as radiation, water and soil due to it's specific underground and above ground morphological structure; therefore, it's intercropping with other suitable crops is a good choice for increasing facilities use efficiency (Zare-Hossiney, 2011). The selected associated crop should not be caused strong shading on saffron and overcome on it or shouldn't need to summer irrigation because it causes corm rot and saffron yield reduction (Koocheki at al., 2009; Zare-Hossiney 2011, Koocheki at al., 2013). Therefore, some legume spices such as Persian clover and pea vine with high growth period coincidence with saffron are good options for intercropping with saffron (Koocheki et al., 2013). Legume cover crops provide a weed control potential, their residue degrade with suitable rapid in soil and have the ability to fix atmospheric nitrogen that potentially provides a nitrogen source to the subsequent or associated crop without the need to additional fertilizer (Kelton et al., 2012; Koocheki et al., 2013). Alfalfa, could be an option for use in rotation with saffron or even as an associated crop, especially about its annual types. Before any decision, it is necessary that take into account the interaction allelopathic activity of the crops in cover crops and crop rotation systems (De-Albuquerque et al., 2011). Results of current experiment didn't show considerable negative effect of saffron on alfalfa initial growth up to middle levels of extract or even showed positive effects especially about corm extract. However, complementary field experiments is need for final decision. 
Tab. 5. Analysis of variance (sum of square) for the effects of different levels of saffron corm and leaf extract on germination and seedling growth indices of alfalfa

\begin{tabular}{|c|c|c|c|c|c|c|c|}
\hline $\begin{array}{c}\text { Mean dry } \\
\text { plumule weight }\end{array}$ & $\begin{array}{l}\text { Mean dry } \\
\text { root weight }\end{array}$ & $\begin{array}{c}\text { Mean } \\
\text { plumule } \\
\text { length }\end{array}$ & $\begin{array}{l}\text { Mean root } \\
\text { length }\end{array}$ & Germination rate & $\begin{array}{c}\text { Germination } \\
\text { percentage }\end{array}$ & Df & $\begin{array}{c}\text { Sources of } \\
\text { variation }\end{array}$ \\
\hline \multicolumn{8}{|c|}{ Leaf extract } \\
\hline $0.0031^{* *}$ & $0.0013^{* *}$ & $29.1^{* *}$ & $12.7^{* *}$ & $231.5^{* *}$ & $16316.6^{* *}$ & 4 & Treatment \\
\hline 0.0002 & 0.0001 & 0.3 & 1.2 & 5.2 & 4466 & 10 & Error \\
\hline 0.0033 & 0.0014 & 29.5 & 13.9 & 236 & 16783 & 14 & Total \\
\hline \multicolumn{8}{|c|}{ Corm extract } \\
\hline $0.00009 \mathrm{~ns}$ & $0.00009 \mathrm{~ns}$ & $0.79 \mathrm{~ns}$ & $7.5^{* *}$ & $25.9^{* *}$ & $43.3 \mathrm{~ns}$ & 4 & Treatment \\
\hline 0.00026 & 0.00020 & 0.89 & 3.0 & 5.1 & 150.0 & 10 & Error \\
\hline 0.00036 & 0.00029 & 1.68 & 10.5 & 31.1 & 193.3 & 14 & Total \\
\hline
\end{tabular}

Tab. 6. Mean comparisons of the effect of different levels of saffron corm and leaf extracts on germination and initial seedling growth criteria of alfalfa

\begin{tabular}{ccccccc}
\hline $\begin{array}{c}\text { Mean dry } \\
\text { plumule weight } \\
(\mathrm{gr})\end{array}$ & $\begin{array}{c}\text { Mean dry root } \\
\text { weight (gr) }\end{array}$ & $\begin{array}{c}\text { Mean plumule } \\
\text { length }(\mathrm{cm})\end{array}$ & $\begin{array}{c}\text { Mean root } \\
\text { length }(\mathrm{cm})\end{array}$ & $\begin{array}{c}\text { Germination rate } \\
(\text { seed per 12 } \\
\text { hours })\end{array}$ & $\begin{array}{c}\text { Germination } \\
\text { percentage }\end{array}$ & $\begin{array}{c}\text { Treatment (extract } \\
\text { concentration) }\end{array}$ \\
\hline $0.036 \mathrm{a}$ & $0.026 \mathrm{a}$ & $3.38 \mathrm{a}$ & $2.06 \mathrm{ab}$ & $12.0 \mathrm{a}$ & $93.3 \mathrm{a}$ & $0.0 \%$ \\
$0.040 \mathrm{a}$ & $0.023 \mathrm{a}$ & $3.98 \mathrm{a}$ & $2.60 \mathrm{a}$ & $9.6 \mathrm{cb}$ & $96.6 \mathrm{a}$ & $0.75 \%$ \\
$0.033 \mathrm{a}$ & $0.020 \mathrm{a}$ & $3.23 \mathrm{~b}$ & $1.58 \mathrm{~b}$ & $8.53 \mathrm{c}$ & $88.3 \mathrm{ab}$ & $1.5 \%$ \\
$0.033 \mathrm{a}$ & $0.020 \mathrm{a}$ & $2.40 \mathrm{c}$ & $0.90 \mathrm{c}$ & $10.0 \mathrm{~b}$ & $80.0 \mathrm{~b}$ & $3.0 \%$ \\
$0.000 \mathrm{~b}$ & $0.000 \mathrm{~b}$ & $00.0 \mathrm{~d}$ & $0.00 \mathrm{~d}$ & $0.63 \mathrm{~d}$ & $8.3 \mathrm{c}$ & $6.0 \%$ \\
& & & Corm extract & & $0.0 \%$ \\
$0.036 \mathrm{a}$ & $0.026 \mathrm{a}$ & $3.38 \mathrm{~b}$ & $2.06 \mathrm{~b}$ & $12.0 \mathrm{a}$ & $93.3 \mathrm{a}$ & $0.75 \%$ \\
$0.033 \mathrm{a}$ & $0.020 \mathrm{a}$ & $3.60 \mathrm{~b}$ & $3.60 \mathrm{a}$ & $8.9 .0 \mathrm{~b}$ & $91.6 \mathrm{a}$ & $1.5 \%$ \\
$0.040 \mathrm{a}$ & $0.020 \mathrm{a}$ & $3.93 \mathrm{ab}$ & $3.45 \mathrm{a}$ & $8.86 \mathrm{~b}$ & $90.0 \mathrm{a}$ & $3.0 \%$ \\
$0.036 \mathrm{a}$ & $0.023 \mathrm{a}$ & $4.01 \mathrm{a}$ & $4.20 \mathrm{a}$ & $9.20 \mathrm{~b}$ & $95.0 \mathrm{a}$ & $6.0 \%$ \\
\hline $.033 \mathrm{a}$ & $0.023 \mathrm{a}$ & $3.80 \mathrm{ab}$ & $3.61 \mathrm{a}$ & $8.23 \mathrm{~b}$ & $93.3 \mathrm{a}$ & 6 \\
\hline
\end{tabular}

Means with the same letters in each column are not significantly different at the 0.05 level of probability.

\section{Conclusions}

In general, growth of selected associated crops affected in different manner in response to saffron leaf and corm extracts. Alfalfa had lowest sensitivity to extract application, especially about corm extract. The allelopathic effects of leaf extract was more than corm extract. Moreover, allelopathic effects of saffron corm and leaf extracts on three selected plants often was inhibitory and sometimes stimulatory, especially about corm extract. It is necessary to study the effects of proposed crops residue on saffron growth, too. In addition, further studies in other growth stages of the plants and under greenhouse and field condition are necessary for final decision on possible use of mentioned associated crops in saffron cultivation, because the concentration and mode of action of allelopathic compounds could be very different in soil environment compared to petri-dish bioassay.

\section{References}

Abbassi F, Jahani M (2008). Allelopathic effects of saffron corms on seed germination of several important crops. Acta Hort 739:269-273.

Akbarpour A, Khorashadizadeh O, Shahidi A, Ghochanian E (2013). Performance evaluation of artificial neural network models in estimate production of yield saffron based on climate parameters. J of Saffron Res 1(1):27-35. (In Persian with English Summary).

Chon SU, Nelson CJ (2010). Allelopathy in Compositae plants. A review. Agron for Sust Dev 30:349-358.

De-Albuquerque MB, Dos-Santos RC, Lima LM, Melo Filho PA, Nogueira RJA, da Camara CAG, Ramos ADR (2011). Allelopathy, an alternative tool to improve cropping systems. A review. Agron for Sust Dev 31:379-395.

Eghbali S, Rashed Mohassel MH, Nassiri Mahallati M, Kazerooni Monfared E (2007). Allelopathic potential of shoot and corm of saffron residues on wheat, rye, vetch and bean. J Field Crops Res 6(2):227-234. (In Persian with English Summary).

Fallahi HR, Rezvani Moghaddam P, Nassiri Mahallati M, Behdani MA, Aghhavani Shajari M, Amiri MB (2013). Influence of seed nitrogen content and biofertilizer priming on wheat germination in salinity stress conditions. Arch Agron Soil Sci 59:791-801.

Fallahi HR, Davarzani J (2013). Allelopathic effects of saffron leaf and corm residue on initial growth of arugula, chickpea and fenugreek in greenhouse condition. Research Programe in Faculty of Agriculture, Sarayan, Iran (In Persian). 
Jakhar ML, Jajoria RN, Sharma KC, Ram S (2010). Genetic Divergence in Taramira (Eruca sativa Mill.). Journal of Oilseed Brassica 1(2):79-83.

Jakse M, Hacin J, Kacjan Marsic N (2013). Production of rocket (Eruca sativa Mill.) on plug trays and on a floating system in relation to reduced nitrate content. Acta Agric Slovenica 101(1):59- 68.

Han X, Cheng Z, Meng H, Yang X, Ahmad I (2013). Allelopathic effects of decoposed garlic (Allium sativum L.) stalk on lettuce (L. satica var. crispal). Pak J Bot 45(1):225233.

Kelton J, Price A, Mosjidis J (2012). Allelopathic weed suppression through the use of cover crops, p. 115-130. In: Price A (Eds.). Weed Control. Publisher InTech.

Khazaei M, Monfared M, Kamgar Haghighi AA, Sepaskhah $A R$ (2013). The trend of change for weight and number of saffron corms as affected by irrigation frequency and method in different years. J Saffron Res 1(1):48-56. (In Persian with English Summary).

Khosravi M (2005). Intercropping black zira (Bonium persicum) with saffron and annual crops: Agroecological and economic perspectives. Ferdowsi Univ., Iran, PhD Diss. (In Persian with English Summary).

Koocheki A, Najibnia S, Lalehgani B (2009). Evaluation of saffron yield (Crocus sativus L.) in intercropping with cereals, pulses and medicinal plants. Iranian J Field Crops Res 7(1): 163-172. (In Persian with English Summary).

Koocheki A, Rezvani Moghaddam P, Fallahi HR (2013). Effects of planting dates, irrigation management and cover crops on growth and yield of saffron (Crocus sativa L.). Agroecology. (In Persian with English Summary).

Kumar R, Virendra S, Kiran D, Sharma M, Singh MK, Ahuja PS (2009). State of art of saffron (Crocus sativus L.) agronomy: A comprehensive review. Food Rev Int 25:4485.

Li Z, Wang Q, Ruan X, Pan C, Jiang D (2010). Phenolics and Plant Allelopathy. Molecules 15: 8933-8952.

Mohammad-Abadi AA, Rezvani-Moghaddam P, Fallahi HR (2011). Effects of planting pattern and the first irrigation date on growth and yield of saffron. J Agroecology 3(1):8493. (In Persian with English Summary).
Moosavi A, Tavakkol Afshari R, Asadi A, Gharineh MH (2011). Allelopathic effects of aqueous extract of leaf, stem and root of Sorghum bicolor on seed germination and seedling growth of Vigna radiata L. Not Sci Biol 3(2):114118.

Naderi Darbaghshahi MR, Banitab AR, Bahari B (2012). Evaluating the possibility of saffron and chamomile mixed culture. African J Agric Res 7(20):3060-3065.

Nasr Isfahan M, Shariati M (2007). The effect of some allelochemicals on seed germination of Coronilla varia $\mathrm{L}$. seeds. Amer-Eurasian J Agri Environ Sci 2 (5):534-538.

Pirzad A, Ghaseian V, Darvishzadeh R, Sedghi M, Hassani A, Onofri A (2010). Allelopathy of sage and white wormwood on purslane germination and seedling growth. Not Sci Biol 2(3):91-95

Rashed-Mohassel MH, Gherekhloo J, Rastgoo M (2008). Allelopathic effects of saffron (Crocus sativus) leaves and corms on seedling growth of redroot pigweed (Amaranthus retroflexus) and lambsquarter (Chenopodium album). J Field Crops Res 7(1):53-61. (In Persian with English Summary).

Rezvani Moghaddam P, Mohammad Abadi AA, Fallahi HR, Aghhavani Shajari M (2011). Response of saffron to planting distances and irrigation times. Proc Medicinal and Aromatic Plants in Generation of New Values in 21th Century. 9-12 November. Sarajevo. Bosnia and Herzegovina. p 137.

Rezvani Moghaddam P, Khorramdel S, Amin Ghafori A, Shabahang J (2013). Evaluation of growth and yield of saffron (Crocus sativus L.) affected by spent mushroom compost and corm density. J Saffron Res 1(1):13-26. (In Persian with English Summary).

Shabahang J, Khorramdel S, Amin Ghafori A, Gheshm R (2013). Effects on management of crop residues and cover crop planting on density and population of weeds and agronomical characteristics of saffron (Crocus sativus L.). J Saffron Res 1(1):57-72. (In Persian with English Summary).

Zare-Hossiney H (2011). Comparison of weed management strategies in saffron. Ferdowsi Univ., Iran, MSc Thes p. 103. (In Persian with English Summary). 